Article

\title{
Toxin Production in Soybean (Glycine max L.) Plants with Charcoal Rot Disease and by Macrophomina phaseolina, the Fungus that Causes the Disease
}

\author{
Hamed K. Abbas ${ }^{1, *}$, Nacer Bellaloui ${ }^{2}$, Cesare Accinelli ${ }^{3}$, James R. Smith ${ }^{2}$ and \\ W. Thomas Shier ${ }^{4, *}$ \\ 1 Biological Control of Pests Research Unit, US Department of Agriculture-Agricultural Research Service, \\ Stoneville, MS 38776, USA \\ 2 Crop Genetics Research Unit, US Department of Agriculture-Agricultural Research Service, Stoneville, \\ MS 38776, USA; nacer.bellaloui@usda.gov (N.B.); rusty.smith@usda.gov (J.R.S.) \\ 3 Department of Agricultural and Food Sciences, Alma Mater Studiorum-University of Bologna, \\ 40127 Bologna, Italy; cesare.accinelli@unibo.it \\ 4 Department of Medicinal Chemistry, College of Pharmacy, University of Minnesota, \\ Minneapolis, MN 55455, USA \\ * Correspondence: hamed.abbas@usda.gov (H.K.A.); shier001@umn.edu (W.T.S.); \\ Tel.: +1-662-686-5313 (H.K.A.); +1-612-624-9465 (W.T.S.)
}

Received: 13 September 2019; Accepted: 29 October 2019; Published: 6 November 2019

check for updates

\begin{abstract}
Charcoal rot disease, caused by the fungus Macrophomina phaseolina, results in major economic losses in soybean production in southern USA. M. phaseolina has been proposed to use the toxin (-)-botryodiplodin in its root infection mechanism to create a necrotic zone in root tissue through which fungal hyphae can readily enter the plant. The majority $(51.4 \%)$ of $M$. phaseolina isolates from plants with charcoal rot disease produced a wide range of (-)-botryodiplodin concentrations in a culture medium $(0.14-6.11 \mu \mathrm{g} / \mathrm{mL}), 37.8 \%$ produced traces below the limit of quantification $(0.01 \mu \mathrm{g} / \mathrm{mL})$, and $10.8 \%$ produced no detectable (-)-botryodiplodin. Some culture media with traces or no (-)-botryodiplodin were nevertheless strongly phytotoxic in soybean leaf disc cultures, consistent with the production of another unidentified toxin(s). Widely ranging (-)-botryodiplodin levels (traces to $3.14 \mu \mathrm{g} / \mathrm{g}$ ) were also observed in the roots, but not in the aerial parts, of soybean plants naturally infected with charcoal rot disease. This is the first report of (-)-botryodiplodin in plant tissues naturally infected with charcoal rot disease. No phaseolinone was detected in M. phaseolina culture media or naturally infected soybean tissues. These results are consistent with (-)-botryodiplodin playing a role in the pathology of some, but not all, M. phaseolina isolates from soybeans with charcoal rot disease in southern USA.
\end{abstract}

Keywords: fungi; mycotoxins; phaseolinone; LC/MS; soybean; charcoal rot disease; root infection mechanism

Key Contribution: This is the first report of a toxin being found in the tissues of soybean plants naturally infected in the field with charcoal rot disease, specifically finding (-)-botryodiplodin and not phaseolinone. This is also the first report of results consistent with some isolates of M. phaseolina using different toxins, other than (-)-botryodiplodin, to facilitate root infection in soybean.

\section{Introduction}

The fungus Macrophomina phaseolina (Tassi) Goidanich [1], also known by the teleomorph Sclerotium bataticola Taub. [2], is the cause of charcoal rot disease, and other named diseases, in soybeans and about 
500 other crop and ornamental species in the United States and internationally [3-5]. Charcoal rot disease, also known as summer wilt, dry weather wilt, or black root disease, results in crop yield loss and seed quality deterioration in soybeans and other crops [6-11]. Charcoal rot disease is more prevalent in heat- and drought-stressed conditions [12,13]. M. phaseolina can spread to adjacent plants with interdigitating roots through the soil, infecting the roots and spreading throughout the infected plant through the vascular system $[14,15]$. M. phaseolina forms black spore-like mycelial structures called microsclerotia, which allow the fungus to survive over winter. These microsclerotia are the grey and black dots in the stems and roots of soybean plants that give charcoal rot disease its name [16]. Common agricultural practices such as managing planting dates, fungicide applications, and biological control have been ineffective in controlling this disease [17-23]. Despite extensive efforts to control charcoal rot disease by developing resistant soybean genotypes [24-26], currently available genotypes are still not sufficiently resistant to prevent the disease in the field, although moderately resistant genotypes have been shown to have lower levels of M. phaseolina in plant tissues [27-29].

The mechanism used by M. phaseolina to infect plants with charcoal rot disease is not yet understood, in part because of the diversity in M. phaseolina isolates [30-33]. M. phaseolina has been reported to produce toxins, including (-)-botryodiplodin and phaseolinone [34-37]. It has been proposed that a toxin may play a role in an early step of the mechanism used by M. phaseolina to infect susceptible plants through the roots from the soil reservoir, where the fungus normally lives, particularly over the winter [7,36].

The objective of the present study is to investigate the involvement of toxins, particularly (-)-botryodiplodin, in the charcoal rot disease of soybeans. Soybeans are selected as the subject for these studies because charcoal rot disease causes major economic losses for soybean production in the midsouthern USA (Mississippi, Arkansas, and Louisiana) [10,11,38-40]. The role(s) of toxins in root infection is investigated in these studies by assessing the production of (-)-botryodiplodin, phaseolinone, and other toxins in cell-free culture filtrates of charcoal rot disease-causing M. phaseolina isolates and in roots and other tissues from soybean plants naturally infected with charcoal rot disease in the field. Studies on the culture filtrates of charcoal rot disease-causing M. phaseolina isolates resulted in the discovery that some, but not all, isolates produce (-)-botryodiplodin, but not phaseolinone, and some isolates that do not produce (-)-botryodiplodin do produce another as yet unknown toxin(s). Studies on toxins present in soybean plant tissues provided the first demonstration of a mycotoxin known to be produced by M. phaseolina in soybean plant tissues naturally infected with charcoal rot disease, specifically (-)-botryodiplodin, but not phaseolinone.

\section{Results and Discussion}

\subsection{Toxin Production in Culture by M. Phaseolina Isolates from Plants with Charcoal Rot Disease}

Toxin production in culture by M. phaseolina isolates from many USA sites and numerous types of plant sources were examined as the toxicity of cell-free culture medium filtrates in soybean leaf disc cultures from two soybean genotypes, DS97-84-1 and DT97-4290 (Table 1). Toxicity assessments with the two genotypes exhibited a similar rank order with no substantive difference between the two, whether assessed at $50 \%$ strength or at full strength. The same cell-free culture filtrates from M. phaseolina isolates were also assayed by LC/MS for levels of (-)-botryodiplodin, the toxin previously [35] found associated with culture filtrates of a M. phaseolina isolate from a soybean plant in Mississippi with charcoal rot disease. Observed concentrations of (-)-botryodiplodin ranged from not detectable to $6.11 \mu \mathrm{g} / \mathrm{mL}$ (Table 1$)$. The majority of isolates (51.4\% of isolates studied) produced quantifiable levels of (-)-botryodiplodin in culture filtrates, while $37.8 \%$ of isolates studied produced trace levels (i.e., above the limit of detection $\left(1 \times 10^{-5} \mathrm{ng} / \mu \mathrm{L}\right)$, but less than the limit of quantitation $\left(1 \times 10^{-2} \mathrm{ng} / \mu \mathrm{L}\right)$, and $10.8 \%$ of isolates studied produced no detectable level of (-)-botryodiplodin in culture filtrates. 
Table 1. Toxicity, color, and (-)-botryodiplodin production in cell-free culture medium filtrates from Macrophomina phaseolina isolates from plants exhibiting charcoal rot disease properties in various states of the USA.

\begin{tabular}{|c|c|c|c|c|c|c|c|c|}
\hline \multirow[b]{3}{*}{ Isolate } & \multirow[b]{3}{*}{ Collection Site } & \multirow[b]{3}{*}{ Plant Host } & \multicolumn{4}{|c|}{ Toxicity a in Leaf Disc Cultures of Two Soybean Genotypes } & \multirow[b]{3}{*}{$\begin{array}{c}\text { Color }{ }^{\mathrm{b}} \text { in One-Week } \\
\text { Cultures }\end{array}$} & \multirow[b]{3}{*}{$\begin{array}{c}\text { (-)-Botryodiplodin }{ }^{c} \\
\text { Concentration }(\mu \mathrm{g} / \mathrm{mL})\end{array}$} \\
\hline & & & \multicolumn{2}{|c|}{ DS97-84-1 } & \multicolumn{2}{|c|}{ DT97-4290 } & & \\
\hline & & & $50 \%$ Strength & $100 \%$ Strength & $50 \%$ Strength & $100 \%$ Strength & & \\
\hline Mp001A & MS & Soybean & ++ & ++ & + & + & beige & Trace \\
\hline$M p 001 \mathrm{~B}$ & MS & Soybean & + & + & + & + & $1 \mathrm{tan}$ & 0.19 \\
\hline Mp004 & MS & Soybean & ++++ & ++++ & +++ & ++++ & $\mathrm{d} \tan$ & 0.18 \\
\hline Mp006A & MS & Soybean & ++ & ++ & + & ++ & 1 yellow & Trace \\
\hline Мp006В & MS & Soybean & ++ & +++ & + & + & $1 \mathrm{tan}$ & 0.14 \\
\hline Mp007 & MS & Soybean & ++ & +++ & ++ & +++ & beige & 0.29 \\
\hline Mp008A & MS & Soybean & + & + & + & + & 1 yellow & 0.15 \\
\hline Mp008B & MS & Soybean & ++ & +++ & ++ & +++ & beige & 0.14 \\
\hline Mp009A & MS & Soybean & ++ & ++ & + & + & $1 \mathrm{tan}$ & Trace \\
\hline Mp010B & MS & Soybean & ++ & ++ & + & + & 1 tan & Trace \\
\hline Mp011A & MS & Soybean & ++ & ++ & +++ & +++ & $1 \tan$ & Trace \\
\hline Mp144 & $\mathrm{KY}$ & Soybean & +++ & +++ & ++ & +++ & beige & 0.18 \\
\hline Mp146 & KY & Soybean & +++ & +++ & ++ & ++ & beige & 0.2 \\
\hline Mp176 & $\mathrm{AR}$ & Soybean & + & + & + & + & 1 yellow & 0.08 \\
\hline$M p 178$ & $\mathrm{AR}$ & Soybean & +++++ & +++++ & +++++ & +++++ & beige & 1.64 \\
\hline$M p 203$ & LA & Soybean & +++ & +++ & +++ & +++ & $\tan$ & Trace \\
\hline Mp204 & LA & Soybean & ++ & ++ & + & + & $1 \tan$ & Trace \\
\hline$M p 214$ & SD & Soybean & +++ & ++++ & +++ & +++ & 1 yellow & Trace \\
\hline$M p 220$ & $\mathrm{TN}$ & Soybean & ++ & ++ & + & + & $1 \tan$ & 0.17 \\
\hline$M p 223$ & $\mathrm{TX}$ & Soybean & +++ & +++ & ++++ & ++++ & $\tan$ & 0 \\
\hline Mp242 & ND & Soybean & + & + & + & + & 1 tan & 0.16 \\
\hline$M p 272$ & $\mathrm{MN}$ & Soybean & ++++ & ++++ & ++++ & ++++ & $1 \mathrm{tan}$ & Trace \\
\hline$M p 279$ & OK & Soybean & +++++ & +++++ & ++++ & +++++ & d grey & 4.03 \\
\hline Mp302 & KS & Soybean & +++ & +++ & ++ & ++ & $1 \tan$ & 0.98 \\
\hline Mp305 & KS & Soybean & ++++ & ++++ & +++ & +++ & $1 \mathrm{tan}$ & Trace \\
\hline$M p 251$ & $\mathrm{NE}$ & Dry bean & ++++ & +++++ & ++++ & +++++ & $\tan$ & 4.5 \\
\hline Mp228 & NC & Fraser fir & + & + & + & + & 1 yellow & 0 \\
\hline$M p 264$ & MI & Fir & +++++ & +++++ & +++++ & +++++ & $\tan$ & 6.11 \\
\hline$M p 275$ & $\mathrm{MN}$ & Redwood & +++++ & +++++ & ++++ & +++++ & $\tan$ & Trace \\
\hline Mp183 & FL & Strawberry & +++ & ++++ & +++ & ++++ & $\tan$ & 0.74 \\
\hline
\end{tabular}


Table 1. Cont

\begin{tabular}{|c|c|c|c|c|c|c|c|c|}
\hline \multirow[b]{3}{*}{ Isolate } & \multirow[b]{3}{*}{ Collection Site } & \multirow[b]{3}{*}{ Plant Host } & \multicolumn{4}{|c|}{ Toxicity $^{\text {a }}$ in Leaf Disc Cultures of Two Soybean Genotypes } & \multirow[b]{3}{*}{$\begin{array}{c}\text { Color }{ }^{b} \text { in One-Week } \\
\text { Cultures }\end{array}$} & \multirow[b]{3}{*}{$\begin{array}{l}\text { (-)-Botryodiplodin }{ }^{c} \\
\text { Concentration }(\mu \mathrm{g} / \mathrm{mL})\end{array}$} \\
\hline & & & \multicolumn{2}{|c|}{ DS97-84-1 } & \multicolumn{2}{|c|}{ DT97-4290 } & & \\
\hline & & & $50 \%$ Strength & $100 \%$ Strength & $50 \%$ Strength & $100 \%$ Strength & & \\
\hline Mp315 & $\mathrm{AZ}$ & Watermelon & ++++ & +++++ & ++++ & +++++ & beige & Trace \\
\hline$M p 249$ & GA & Unknown & +++++ & +++++ & ++++ & ++++ & $\tan$ & 2.04 \\
\hline Mp216 & Unknown & Unknown & ++++ & ++++ & +++ & +++ & 1 grey & 0.31 \\
\hline Mp234 & Unknown & Unknown & ++++ & ++++ & ++++ & ++++ & $\tan$ & 0 \\
\hline Mp235 & Unknown & Unknown & + & + & + & + & $1 \tan$ & Trace \\
\hline$M p 238$ & Unknown & Unknown & + & + & + & + & $1 \tan$ & 0 \\
\hline Mp239 & Unknown & Unknown & + & + & + & + & $1 \tan$ & Trace \\
\hline \multicolumn{9}{|c|}{$\begin{array}{l}\text { Abbreviations: Macrophomina phaseolina, Mp; Mississippi, MS; Kentucky, KY; Arkansas, AR; Louisiana, LA; South Dakota, SD; Tennessee, TN; Texas, TX; North Dakota, ND; Minnesota, MN; } \\
\text { Oklahoma, OK; Kansas, KS; Nebraska, NE; North Carolina, NC; Michigan, MI; Florida, FL; Arizona, AZ; Georgia, GA; light, l; dark, d. a Toxicity score measured in soybean leaf disc } \\
\text { cultures of two soybean genotypes: (i) DT97-4290, which is moderately resistant to charcoal rot disease and (ii) DS97-84-1, which is susceptible to charcoal rot disease. Toxicity was assessed } \\
\text { qualitatively according to the following symptom rating scale: healthy tissue }<\text { a little browning around the edges of the leaf disc, }+<\text { moderate browning around the edges of the leaf } \\
\text { disc, }++<\text { browning of the whole leaf disc, }+++<\text { browning of the leaf disc with some photobleaching, }++++<\text { photobleaching of the whole leaf disc, }+++++ \text {. }{ }^{b} \text { Color density was } \\
\text { assessed qualitatively according to the following color density scale: whitish }<\text { light yellow }<\text { light tan }<\text { light grey }<\text { tan }<\text { beige or amber }<\text { dark tan }<\text { dark brown or dark grey }<\text { black. c } \\
\text { (-)-Botryodiplodin concentrations in culture medium filtrates }\end{array}$} \\
\hline
\end{tabular}


Whether M. phaseolina isolates were from trees, soybeans, melons, or other plant sources, cell-free culture filtrates were toxic in soybean leaf disc cultures, and toxicity levels varied from not detectable to very toxic (Table 1). Culture filtrates from M. phaseolina isolates that contained high levels of (-)-botryodiplodin $(>1 \mu \mathrm{g} / \mathrm{mL})$ were all very toxic in soybean leaf disc cultures, resulting in maximal or near maximal toxicity with both DT97-4290 and DS97-84-1 soybean leaf discs at 100\% and 50\% strength. Culture filtrates that contained intermediate levels of (-)-botryodiplodin $(0.2-1.0 \mu \mathrm{g} / \mathrm{mL})$ were moderately toxic in soybean leaf disc cultures. However, some other M. phaseolina isolate culture filtrates that contained only trace levels or even no detectable (-)-botryodiplodin were highly toxic in soybean leaf disc cultures. This observation is consistent with some disease-inducing isolates of M. phaseolina producing one or more toxins other than (-)-botryodiplodin. This is the first report of results supporting the hypothesis that different isolates of $M$. phaseolina may use different toxins to facilitate root infection in soybeans. Further studies are needed to determine if any of those isolates use the other toxin(s) to facilitate root infection by a mechanism analogous to the one by which (-)-botryodiplodin might facilitate root infection. Some culture filtrates from the disease-inducing isolates of M. phaseolina contained very little toxicity in soybean leaf disc cultures, despite the isolate being able to cause charcoal rot disease. Explanations for this observation include the possible presence of a toxin-production regulatory mechanism that suppresses toxin production by those isolates under the culture conditions used in this study, or the possibility that charcoal rot disease in soybeans may be caused by a seed-borne M. phaseolina endophyte that would not need a root infection mechanism or any toxins associated with it [14]. The M. phaseolina isolate from which phaseolinone was originally isolated [34,37] was a seed-borne endophyte.

Also included in Table 1 is an assessment of the color of week-old cultures of M. phaseolina. Dunlap and Bruton [41] reported that a M. phaseolina isolate formed pigment in an infected muskmelon (Cucumis melo) and in liquid culture media containing glycine and some other amino acids. Some M. phaseolina isolates that cause charcoal rot disease in soybeans have been observed to form large numbers of black microschlerotia under the same culture conditions that induce the production of (-)-botryodiplodin [42]. In the data in Table 1, the rank order of pigment production, as assessed qualitatively according to the color density scale used, differed substantially from the rank order of toxicity in cell-free culture filtrates as assessed in soybean leaf disc cultures at either full strength or $50 \%$ dilution and from the relative amount of (-)-botryodiplodin present as measured by LC/MS. Thus, pigment production as assessed in this study appeared to be unrelated to toxin production, consistent with the previously identified correlations not being a general phenomenon when larger numbers of M. phaseolina isolates are examined.

\subsection{Analysis of Toxin Levels in Tissue Samples from Soybean Plants Naturally Infected with Charcoal Rot Disease}

If the hyphae of a M. phaseolina strain that causes charcoal rot disease use a toxin(s) to create a necrotic area in the root and thereby facilitate entry into soybean plant roots from a soil reservoir, those hyphae are expected to produce a toxin(s) at least from the time the fungus detects the root in the soil until the fungal hyphae inside the plant have detected that a stable infection has been established there. Fungi that spread from plant to plant through interdigitating roots, as M. phaseolina does in the charcoal rot disease of soybeans, may also secrete a toxin(s) inside the roots of fully infected plants in order to create a necrotic area within the root from which hyphae may exit the plant to spread to adjacent plants. Thus, soybean plants exhibiting the symptoms of charcoal rot disease may contain a chemically and metabolically stable toxin in tissues at a level detectable by standard analytical methods such as LC/MS. If the M. phaseolina strain causing charcoal rot disease in a soybean plant is a constitutive (continuous) producer of the toxin, comparable levels of the toxin may be expected in all the affected tissues of diseased plants. Therefore, naturally infected soybean plants exhibiting symptoms of charcoal rot disease were collected from different infected areas in commercial soybean production fields in Mississippi in the 2004 growing season. Control soybean plants not exhibiting 
symptoms of charcoal rot disease were also collected. Samples of roots, leaves, stem pulp, branches, twigs, and seeds were individually extracted and analyzed by LC/MS for levels of (-)-botryodiplodin, phaseolinone, phomenone, and gigantenone (Table 2). Only (-)-botryodiplodin was detected and only in the roots of soybean plants exhibiting symptoms of charcoal rot disease, not in other tissues of diseased plants and not in the roots or any other tissues of control soybean plants not exhibiting symptoms of charcoal rot disease. This is the first report of a toxin being found in infected plant tissues associated with charcoal rot disease in soybeans. This observation would be expected if M. phaseolina used (-)-botryodiplodin in its mechanism for (i) initial root infection and (ii) to exit heavily infected plants in order to spread to and infect adjacent plants. However, additional studies are needed to establish a role for (-)-botryodiplodin in either the initial root infection or the root exit mechanism. No phaseolinone, phomenone, or gigantenone was found in any tissue of soybean plants with charcoal rot disease in this study. As shown in Table 3, these observations are confirmed by a similar study conducted in 2007, in which root tissue was collected from naturally infected soybean plants from commercial production fields in Mississippi and Kentucky, USA, and analyzed by LC/MS for levels of (-)-botryodiplodin, phaseolinone, phomenone, and gigantenone. As observed in the first study (Table 2), only (-)-botryodiplodin was detected in diseased roots, not phaseolinone, phomenone, or gigantenone. Again, (-)-botryodiplodin levels varied from traces to $3.14 \mu \mathrm{g} / \mathrm{g}$, that is, greater than a 1000 -fold concentration range. The wide range of (-)-botryodiplodin levels in charcoal rot-diseased soybean roots (Tables 2 and 3) paralleled the wide range of (-)-botryodiplodin production levels in cell-free culture filtrates of M. phaseolina isolates from plants with charcoal rot disease. In both experimental systems, there were a substantial number of cases in which (-)-botryodiplodin production was too low for it to be a toxin that could play a role in the pathology caused by those M. phaseolina strains, whether by facilitating root infection or any other mechanism. 
Table 2. Mycotoxin levels in root and other tissues of soybean plants collected from soybean fields in Mississippi in 2004.

\begin{tabular}{|c|c|c|c|c|c|c|}
\hline Sample Name & Charcoal Rot Disease & Soybean Tissue Type & $(-)$-Botryodiplodin $(\mu \mathrm{g} / \mathrm{g})^{a}$ & Phomenone $(\mu \mathrm{g} / \mathrm{g})^{\mathrm{a}}$ & Gigantenone $(\mu \mathrm{g} / \mathrm{g})^{a}$ & Phaseolinone $(\mu \mathrm{g} / \mathrm{g})^{\mathrm{a}}$ \\
\hline RTS 999302 & Yes & Roots & 0.786 & 0 & 0 & 0 \\
\hline USG 7582306 & Yes & Roots & 0.13 & 0 & 0 & 0 \\
\hline DK B58-51 326 & Yes & Roots & 0.23 & 0 & 0 & 0 \\
\hline AG 5903324 & Yes & Roots & 0.046 & 0 & 0 & 0 \\
\hline AG 5701329 & Yes & Roots & 0.139 & 0 & 0 & 0 \\
\hline PGX 5703313 & Yes & Roots & 0.334 & 0 & 0 & 0 \\
\hline PGY 5822319 & Yes & Roots & 0.332 & 0 & 0 & 0 \\
\hline ESXVT-46 328 & Yes & Roots & 0.134 & 0 & 0 & 0 \\
\hline Р 95 B96 301 & Yes & Roots & 0.006 & 0 & 0 & 0 \\
\hline P GX 5714311 & Yes & Roots & 0.141 & 0 & 0 & 0 \\
\hline Garst 5812331 & Yes & Roots & 0.209 & 0 & 0 & 0 \\
\hline DK 576732 & Yes & Roots & 0.061 & 0 & 0 & 0 \\
\hline All samples tested & Yes & Seeds & 0 & 0 & 0 & 0 \\
\hline All samples tested & Yes & Pulp & 0 & 0 & 0 & 0 \\
\hline All samples tested & Yes & Branches & 0 & 0 & 0 & 0 \\
\hline All samples tested & Yes & Twigs & 0 & 0 & 0 & 0 \\
\hline All samples tested & Yes & Leaves & 0 & 0 & 0 & 0 \\
\hline Undiseased control $^{\mathrm{b}}$ & No & Roots & 0 & 0 & 0 & 0 \\
\hline
\end{tabular}

${ }^{a}$ Identification and quantification of toxins in samples by LC/MS were based on one standard due to the limited amount of standards available. ${ }^{b}$ Soybean plants of the Saline cultivar with no detectable sign of charcoal rot disease were collected from commercial fields in Mississippi. Samples of the same six tissues were taken, pooled, and extracted in the same way as tissues from diseased plants and the extracts were assayed by LC/MS in the same manner. Extracts of all undiseased soybean tissues, including roots, contained no detectable (-)-botryodiplodin or other toxin 
Table 3. Toxins in the roots of soybean plants exhibiting charcoal rot disease properties collected from commercial soybean fields in Kentucky and Mississippi in 2007.

\begin{tabular}{ccccc}
\hline Field and Location * & $\begin{array}{c}\text { (-)-Botryodiplodin } \\
(\mu \mathrm{g} / \mathrm{g})\end{array}$ & $\begin{array}{c}\text { Phomenone } \\
(\mu \mathrm{g} / \mathrm{g})\end{array}$ & $\begin{array}{c}\text { Gigantenone } \\
(\mu \mathrm{g} / \mathrm{g})\end{array}$ & $\begin{array}{c}\text { Phaseolinone } \\
(\mu \mathrm{g} / \mathrm{g})\end{array}$ \\
\hline $1 \mathrm{KY}$ & 0.870 & 0 & 0 & 0 \\
$417 \mathrm{MS}$ & trace & 0 & 0 & 0 \\
$1 \mathrm{KY}$ & 0.567 & 0 & 0 & 0 \\
$314 \mathrm{MS}$ & 3.139 & 0 & 0 & 0 \\
$3 \mathrm{KY}$ & 0.114 & 0 & 0 & 0 \\
$4 \mathrm{KY}$ & 0.115 & 0 & 0 & 0 \\
$2 \mathrm{KY}$ & 0.938 & 0 & 0 & 0 \\
$209 \mathrm{MS}$ & 0.757 & 0 & 0 & 0 \\
$4 \mathrm{KY}$ & 0.946 & 0 & 0 & 0 \\
$312 \mathrm{MS}$ & 0.703 & 0 & 0 & 0 \\
$210 \mathrm{P} 12 \mathrm{MS}$ & trace & 0 & 0 & 0 \\
\hline
\end{tabular}

* Soybean plants exhibiting symptoms of charcoal rot disease were collected in the indicated commercial field numbers in the indicated states, brought to the laboratory, tissues harvested and stored at $-20{ }^{\circ} \mathrm{C}$ until assayed. Soybean root samples had symptoms of charcoal rot and were run by LC/MS. Determination and quantification of these mycotoxins was by LC/MS based on one standard because a limited amount of these standards were available.

\section{Conclusions}

A wide range of (-)-botryodiplodin levels were observed in both cell-free culture medium filtrates from M. phaseolina isolates from plants with charcoal rot disease and in the roots, but not in the aerial parts, of soybean plants naturally infected with charcoal rot disease. Cell-free culture medium filtrates from some M. phaseolina isolates from plants with charcoal rot disease were strongly phytotoxic, despite containing only traces or no (-)-botryodiplodin. No phaseolinone was detected in either cell-free culture medium filtrates from M. phaseolina isolates or in tissues from soybean plants naturally infected with charcoal rot disease. The results of this study are consistent with some, but not all, isolates of M. phaseolina associated with charcoal rot disease in soybean-producing (-)-botryodiplodin. Some isolates of $M$. phaseolina cultured from soybean plants with charcoal rot disease produce no detectable (-)-botryodiplodin in culture, but do produce other unknown toxins. Further research is needed to determine what role, if any, (-)-botryodiplodin and other toxins produced by M. phaseolina isolates play in the root infection mechanism of the charcoal rot disease of soybeans.

\section{Materials and Methods}

\subsection{Soybean Plant and Greenhouse Conditions}

The soybean genotype DT97-4290 [28] was selected as an example of a genotype that is moderately resistant to charcoal rot disease, and the soybean genotype DS97-84-1 [43] was selected as an example of a genotype that is susceptible to charcoal rot disease. Plants were germinated in trays with vermiculite, and the seedlings of each genotype were transplanted into six soil-filled $9.45 \mathrm{~L}$ pots, each containing four plants of the same genotype. During the growth period, the soil water potential of the plants was maintained at approximate field conditions, 15 to $-20 \mathrm{kPa}$. Six pots, each containing four plants, were used for each genotype. The greenhouse temperature was set to $34^{\circ} \mathrm{C}$ for the day cycle and $28{ }^{\circ} \mathrm{C}$ for the night cycle. Light intensity ranged from that of sunny to cloudy days. Plants were harvested during the vegetative stage.

\subsection{M. phaseolina Culture Sources}

The collection locations and plant hosts of the 37 cultures of $M$. phaseolina used in the study are presented in Table 1. Some M. phaseolina cultures were isolated from infected plant tissues in the Abbas laboratory in 2013 using the method of Mengistu et al. [4,25], while other cultures were provided by colleagues from their collections, particularly G.L. Sciumbato, Mississippi State University. 


\subsection{Preparation of Cell-Free Culture Extracts}

Potato dextrose broth (PDB) was prepared by boiling $200 \mathrm{~g}$ of peeled potatoes, straining them through a cheesecloth, and adding $20 \mathrm{~g}$ of dextrose per liter of water. PDB $(150 \mathrm{~mL})$ was placed in $500 \mathrm{~mL}$ Erlenmeyer flasks, covered with cotton plugs, autoclaved for $15 \mathrm{~min}$, and allowed to cool to room temperature. Upon cooling, each flask was inoculated with three to four plugs of M. phaseolina isolate and placed on an Innova 40 Benchtop Incubator Shaker (New Brunswick Scientific Co., Inc., Edison, NY, USA) for seven days at $128 \mathrm{rpm}, 28^{\circ} \mathrm{C}$. The color change of each culture after one week of incubation was observed and recorded according to the following color density scale: whitish $<$ light yellow $<$ light $\tan <$ light grey $<\tan <$ beige or amber $<$ dark $\tan <$ dark brown or dark grey $<$ black.

After seven days of incubation, the culture medium was passed through Whatman No.1 filter paper into a plastic beaker. The filtrate was then filtered through an $0.45 \mu \mathrm{m}$ membrane filter in a disposable filter unit (Nalgene Company, Rochester, NY, USA, Size $250 \mathrm{~mL}$ cellulose nitrate CN Filter Unit) using a laboratory vacuum to achieve a cell-free filtrate that was stored at $-20^{\circ} \mathrm{C}$ until used.

\subsection{Toxicity of Cell-Free Filtrates of M. phaseolina Culture Media in Soybean Leaf Disc Cultures}

The toxicity of M. phaseolina culture filtrates was assessed by rating the appearance of soybean leaf discs from two genotypes (DT97-4290, which is moderately resistant to charcoal rot, and DS97-84-1, which is susceptible) after four to five days in half $(50 \%)$ and full strength $(100 \%)$ cell-free culture filtrates, M. phaseolina isolates were grown on potato dextrose agar (PDA) for seven days at $28{ }^{\circ} \mathrm{C}$. True mature leaves with no signs of damage were harvested from 3- to 4-week-old soybean plants, and $4 \mathrm{~mm}$ discs were cut from the leaves using a sterile cork borer (No.4). Three leaf discs were placed in each well of sterile 24-well tissue culture trays with low evaporative lids (Becton Dickinson and Company, Franklin Lakes, NJ, USA) containing $1.5 \mathrm{~mL}$ of culture filtrate in triplicate at two concentrations $(50 \%$ and $100 \%)$. The trays were then incubated in a growth chamber at $25{ }^{\circ} \mathrm{C}$ under continuous light for $96 \mathrm{~h}$. The discs were observed for signs of toxic effects after 24, 48, 72, and $96 \mathrm{~h}$. Toxicity was assessed qualitatively according to the following symptom rating scale: healthy tissue $<$ a little browning around the edges of the leaf disc, $+<$ moderate browning around the edges of the leaf disc, $++<$ browning of the whole leaf disc, $+++<$ browning of the leaf disc with some photobleaching, $++++<$ photobleaching of the whole leaf disc, +++++ .

\subsection{Toxin Standards for LC/MS Analyses}

The structures of toxins measured in this study are presented in Figure 1. $( \pm)$-Botryodiplodin was synthesized, as described in the accompanying manuscript [44], as a white powder with purity over $98 \%$. A stock solution of $( \pm)$-botryodiplodin $(1000 \mathrm{ng} / \mu \mathrm{L})$ was prepared in chloroform. Working standards were prepared in the concentration range $1.0 \times 10^{-5} \mathrm{ng} / \mu \mathrm{L}$ to $40 \mathrm{ng} / \mu \mathrm{L}$ in ethyl acetate. Gigantenone and phomenone were gifts from Gary A. Strobel, Montana State University, Bozeman, MT. Phaseolinone was synthesized (Figure 2) from a sample of the phomenone (6.5 $\mathrm{mg}, 0.0246 \mathrm{mmole}$ ) dissolved in $1 \mathrm{~mL}$ chloroform and mixed with a 1.2 molar excess of m-chloroperoxybenzoic acid (Acros Organics, 0.029 mmole, $7.15 \mathrm{mg}$ of $70 \%$ pure material) and pyridine $(4.7 \mu \mathrm{L}, 4.6 \mathrm{mg}, 0.058 \mathrm{mmole})$ dissolved in $200 \mu \mathrm{L}$ chloroform. The mixture was incubated for $1 \mathrm{~h}$ at $-10^{\circ} \mathrm{C}$ with stirring and then allowed to warm to room temperature overnight. The reaction mixture was diluted with ether, extracted twice with water, once with $1 \mathrm{~N} \mathrm{HCl}$ to remove pyridine, twice with saturated sodium bicarbonate-brine solution to remove product $\mathrm{m}$-chlorobenzoic acid and unreacted $\mathrm{m}$-chloroperoxybenzoic acid, dried over anhydrous sodium sulfate, and evaporated in vacuo. The product $(7.5 \mathrm{mg})$ gave a single peak at $m / e 281$ (phaseolinone $+\mathrm{H}^{+}$) in LC/MS analysis under the conditions described below, with no detectable phomenone starting material at $m / e$ 265. A single peak was observed in LC/MS for the phaseolinone preparation, even though the reaction conditions would be expected to produce a mixture of phaseolinone and epi-phaseolinone, presumably because the two forms were not resolved under the liquid chromatography conditions used. 
<smiles>CC(=O)[C@@H]1COC(O)[C@@H]1C</smiles>

(-)-Botryodiplodin<smiles>C[C@@H]1C(=O)[C@H]2C(=CC(=O)[C@@]2(C)[C@H]2CO2)CC[C@@H]1O</smiles>

Gigantenone<smiles>C[C@H]1[C@H](O)CCC2=CC(=O)[C@@](C(=O)CO)(C3CO3)C[C@]21C</smiles>

Phaseolinone<smiles></smiles>

Phomenone

Figure 1. Chemical structures of the toxins measured by LC/MS in M. phaseolina culture media and soybean root tissues.<smiles>C=C(CO)[C@]12O[C@@H]1[C@@]1(C)C(=CC2=O)CC[C@H](O)[C@@H]1C</smiles>

Phomenone<smiles>C[C@H]1[C@@H](O)CCC2=CC(=O)[C@]3(COCC3CO)O[C@@H]2[C@]1(C)CC(=O)Br</smiles>

Phaseolinone + epi-Phaseolinone

Figure 2. The chemical reaction used in the semi-synthesis of the LC/MS standard phaseolinone from the natural toxin phomenone. MCPBA = meta-chloroperoxybenzoic acid.

\subsection{Preparation of Plant Tissue and M. phaseolina Culture Medium Extracts for LC/MS Analyses}

Soybean root and other tissue samples were cleaned of adherent earth, dried in an oven at $45^{\circ} \mathrm{C}$ for two to three days, and ground to the consistency of flour using a Stain Laboratory Mill Grinder, Model M-2 (Fred Stein Laboratories, INC., Atchison, Kansas, USA). Ethyl acetate (10 g) was added to $50 \mathrm{~g}$ of each sample, shaken for $1 \mathrm{~h}$, filtered through filter paper (Whatman No.1), and transferred to vials for analysis by LC/MS as described below. M. phaseolina culture medium cell-free filtrate samples were extracted with ethyl acetate in a 1:1, v:v ratio on a vortex mixer for $1 \mathrm{~min}$ and allowed to separate into two distinct layers. The ethyl acetate layer was transferred to vials for analysis by LC/MS.

\subsection{LC/MS Analysis}

LC/MS analyses of toxin samples obtained prior to 2007 were conducted on a Thermo Finnigan LCQ Advantage instrument coupled to a Thermo Finnigan Surveyor MS and a Thermo Finnigan Surveyor MS Pump (Thermo Electron Corporation, West Palm Beach, FL, USA). After 2007, a more advanced and upgraded LTQ XL Ion Trap Mass Spectrometer, Finnigan Surveyor Autosampler, and Finnigan Surveyor MS Pump (Thermo Scientific, West Palm Beach, FL, USA) were used. Analyses were carried out in positive scan mode at ambient temperature using a Waters Nova-Pak C18 column, a $10 \mu \mathrm{L}$ partial loop injection, and mobile phases (A) $1 \%$ acetic acid in methanol, (B) water, and (C) methanol at a flow rate of $500 \mu \mathrm{L} / \mathrm{min}$. The analysis occurred over $25 \mathrm{~min}$ using a gradient of $20 \% \mathrm{~A}$ and $80 \% \mathrm{~B}$ for $12 \mathrm{~min}$, then $20 \% \mathrm{~A}, 5 \% \mathrm{~B}$, and $75 \% \mathrm{C}$ for $3 \mathrm{~min}$, and then back to $20 \% \mathrm{~A}$ and $80 \% \mathrm{~B}$ for the duration of the $25 \mathrm{~min}$. The analysis utilized the following scan events of a full scan from $\mathrm{m} / \mathrm{e} 100$ to 300 . The confirmation of (-)-botryodiplodin used three masses: $m / e 127,145$, and 109 . The limit of 
detection (LOD) was $1 \times 10^{-5} \mu \mathrm{g} / \mathrm{mL}$ and the limit of quantitation (LOQ) was $0.01 \mu \mathrm{g} / \mathrm{mL}$. The LOQ was based on the regression of the standards used for analysis. The full scan run of phomenone, gigantenone, and phaseolinone was from $\mathrm{m} / \mathrm{e} 100$ to 500, and their confirmations were identified by using $m / e$ 265, 265, and 281 , respectively.

\subsection{Statistical Analysis}

The analysis of variance was performed on toxin concentration data using the PROC GLM procedure in SAS Version 9.22 (Cary, NC, USA, 2010). Means were separated by Fisher's Least Significant Difference test with $p \leq 0.05$ level of significance.

Author Contributions: Conceptualization, H.K.A., N.B., C.A., J.R.S., W.T.S.; methodology, H.K.A., W.T.S.; validation, H.K.A.; investigation, H.K.A., W.T.S.; resources, H.K.A., W.T.S.; data curation, H.K.A., W.T.S.; writing—original draft preparation, H.K.A., W.T.S.; writing—review and editing, H.K.A., N.B., C.A., J.R.S., W.T.S.; visualization, W.T.S.; supervision, H.K.A.; project administration, H.K.A.; funding acquisition, H.K.A., W.T.S.

Funding: This research was funded by the Mississippi Soybean Promotion Board, grant numbers 34-2016 and 34-2017.

Acknowledgments: The authors are grateful to Alemah Butler, Bobbie J. Johnson (retired), Jeremy Kotowicz, and Vivek H. Khambhati for their technical assistance. Also, the authors are grateful for G.L. Sciumbato (retired) for supplying cultures and plant samples. Trade names are used in this publication solely for the purpose of providing specific information. The mention of trade names or commercial products in this publication is solely for the purpose of providing specific information and does not imply recommendation or endorsement by the United States Department of Agriculture.

Conflicts of Interest: All authors declare no conflict of interest.

\section{References}

1. Dhingra, O.D.; Sinclair, J.B. Location of Macrophomina phaseoli on soybean plants related to culture characteristics and virulence. Phytopathology 1973, 63, 934-936. [CrossRef]

2. Holliday, P.; Punithalingam, E. Macrophomina Phaseolina; No. 275; Descriptions of Pathogenic Fungi and Bacteria; CMI: Kew, Surrey, UK, 1970.

3. Ghosh, T.; Biswas, M.K.; Guin, C.; Roy, P. A review on characterization, therapeutic approaches and pathogenesis of Macrophomina phaseolina. Plant Cell Biotechnol. Mol. Biol. 2018, 19, 72-84.

4. Mengistu, A.; Ray, J.D.; Smith, J.R.; Paris, R.L. Charcoal rot disease assessment of soybean genotypes using a colony-forming unit index. Crop Sci. 2007, 47, 2453-2461. [CrossRef]

5. Wyllie, T.D. Macrophomina phaseolina-Charcoal rot. In World Soybean Research: Proceedings of the World Soybean Research Conference; Hill, L.D., Ed.; Interstate Printers and Publishers Inc.: Danville, IL, USA, 1976; pp. 482-484.

6. Bellaloui, N.; Mengistu, A.; Paris, R.L. Soybean seed composition in cultivars differing in resistance to charcoal rot (Macrophomina phaseolina). J. Agric. Sci. 2008, 146, 667-675. [CrossRef]

7. Bellaloui, N.; Mengistu, A.; Zobiole, L.H.S.; Shier, W.T. Resistance to toxin-mediated fungal infection: Role of lignins, isoflavones, other seed phenolics, sugars and boron in the mechanism of resistance to charcoal rot disease in soybean. Toxin Rev. 2012, 31, 16-26. [CrossRef]

8. Bowen, C.R.; Schapaugh, W.T., Jr. Relationship among charcoal rot infection, yield, and stability estimates in soybean blends. Crop Sci. 1989, 29, 42-46. [CrossRef]

9. Gupta, G.K.; Sharma, S.K.; Ramteke, R. Biology, epidemiology and management of the pathogenic fungus Macrophomina phaseolina (Tassi) Goid with special reference to charcoal rot of soybean (Glycine max (L.) Merrill). J. Phytopathol. 2012, 160, 167-180. [CrossRef]

10. Wrather, J.A. Soybean disease loss estimates for the southern United States, 1974 to 1994. Plant Dis. 1995, 79, 1076-1079.

11. Wrather, J.A.; Koenning, S.R. Estimates of disease effects on soybean yields in the United States 2003-2005. J. Nematol. 2006, 38, 173-180.

12. Illinois Soybean Association. Ideas that Elevate; Research report; Illinois Soybean Association: Bloomington, IL, USA, 2010; pp. 2-16. 
13. Smith, G.S.; Wyllie, T.D. Charcoal rot. In Compendium of Soybean Diseases, 4th ed.; Hartman, G.L., Sinclair, J.B., Rupe, J.C., Eds.; APS Press, The American Phytopathological Society: St. Paul, MN, USA, 1999; pp. $29-31$.

14. Gangopadhyay, S.; Wyllie, T.D.; Luedders, V.D. Charcoal rot disease of soybean transmitted by seeds. Plant Dis. Rep. 1970, 54, 1088-1091.

15. Kaiser, W.J.; Horner, G.M. Root rot of irrigated lentils in Iran. Can. J. Bot. 1980, 58, 2549-2556. [CrossRef]

16. Abawi, G.S.; Pastor-Corrales, M.A. Root Rots of Beans in Latin America and Africa; Diagnosis, Research Methodologies and Management Strategies; International Center for Tropical Agriculture (CIAT): Palmira, Cali, Columbia, 1990; p. 114.

17. Francl, L.J.; Wyllie, T.D.; Rosenbrock, S.M. Influence of crop rotation on population density of Macrophomina phaseolina in soil infested with Heterodora glycines. Plant Dis. 1988, 72, 760-764. [CrossRef]

18. Ghaffar, A.; Zentmyer, G.A.; Erwin, D.C. Effect of organic amendments on severity of Macrophomina phaseolina root rot of cotton. Phytopathology 1969, 59, 1267-1269.

19. Mueller, J.D.; Short, B.J.; Sinclair, J.B. Effect of cropping history, cultivar, and sampling date on the internal fungi of soybean roots. Plant Dis. 1985, 69, 520-523. [CrossRef]

20. Rothrock, C.S.; Kirkpatrick, T.L. The influence of winter legume cover crops on soilborne plant pathogens and cotton seedling diseases. Plant Dis. 1995, 79, 167-171. [CrossRef]

21. Siddiqui, Z.A.; Mahmood, I. Biological control of Meloidogyne incognita race 3 and Macrophomina phaseolina by Paecilomyces lilacinus and Bacillus subtilis alone and in combination in chickpea. Fund. Appl. Nematol. 1993, 16, 215-218.

22. Todd, T.C. Soybean planting date and maturity effects on Hetrodera glycines and Macrophomina phaseolina on southeastern Kansas. Suppl. J. Nematol. 1993, 25, 731-737.

23. Wyllie, T.D.; Scott, D.H. (Eds.) Charcoal rot of soybean-current status. In Soybean Diseases of the North Central Region; American Phytopathological Society: St. Paul, MN, USA, 1988; pp. 106-113.

24. Kendig, S.R.; Rupe, J.C.; Scott, H.D. Effect of irrigation and soil water stress on densities of Macrophomina phaseolina in soil and roots of two soybean cultivars. Plant Dis. 2000, 84, 895-900. [CrossRef]

25. Mengistu, A.; Arelli, P.A.; Bond, J.P.; Shannon, G.J.; Wrather, A.; Rupe, J.B.; Chen, P.; Little, C.R.; Canaday, C.H.; Newman, M.A.; et al. Evaluation of soybean genotypes for resistance to charcoal rot. Plant Health Prog. 2011. [CrossRef]

26. Smith, G.S.; Carvil, O.N. Field screening of commercial and experimental soybean cultivars for their reaction to Macrophomina phaseolina. Plant Dis. 1997, 81,363-368. [CrossRef]

27. Mengistu, A.; Ray, J.D.; Smith, J.R.; Arelli, P.R.; Bellaloui, N.; Chen, P.; Shannon, G.; Boykin, D. Effect of charcoal rot on selected putative drought tolerant soybean genotypes and yield. Crop Prot. 2018, 105, 90-101. [CrossRef]

28. Paris, R.L.; Mengistu, A.; Tyler, J.M.; Smith, J.R. Registration of soybean germplasm line DT97-4290 with moderate resistance to charcoal rot. Crop Sci. 2006, 46, 2324-2325. [CrossRef]

29. Smith, J.R.; Ray, J.D.; Mengistu, A. Genotypic differences in yield loss of irrigated soybean attributable to charcoal rot. J. Crop Improv. 2018, 32, 781-800. [CrossRef]

30. Dhingra, O.D.; Sinclair, J.B. Variation among isolates of Macrophomina phaseoli (Rhizoctonia bataticola) from the same soybean plant. Phytopathology 1972, 62, S1108.

31. Jana, T.K.; Singh, N.K.; Koundal, K.R.; Sharma, T.R. Genetic differentiation of Charcoal rot pathogen, Macrophomina phaseolina, into specific groups using URP-PCR. Can. J. Microbiol. 2005, 51, 159-164. [CrossRef]

32. Mayék-Pérez, N.; López-Castañeda, C.; González-Chavira, M.; Garcia-Espinosa, R.; Acosta-Gallegos, J.; de la Vega, O.M.; Simpson, J. Variability of Mexican isolates of Macrophomina phaseolina based on pathogenesis and AFLP genotype. Physiol. Mol. Plant Pathol. 2001, 59, 257-264. [CrossRef]

33. Reyes-Franco, M.C.; Hernández-Delgado, S.; Beas-Fernández, R.; Medina-Fernández, M.; Simpson, J.; Mayek-Pérez, N. Pathogenic and genetic variability within Macrophomina phaseolina from Mexico and other countries. J. Phytopathol. 2006, 154, 447-453. [CrossRef]

34. Dhar, T.K.; Siddiqui, K.A.I.; Ali, E. Structure of phaseolinone, a novel phytotoxin from Macrophomina phaseolina. Tetrahedron Lett. 1982, 23, 5459-5462.

35. Ramezani, M.; Shier, W.T.; Abbas, H.K.; Tonos, J.L.; Baird, R.E.; Sciumbato, G.L. Soybean charcoal rot disease fungus Macrophomina phaseolina in Mississippi produces the phytotoxin, (-)-botryodiplodin, but no detectable phaseolinone. J. Nat. Prod. 2007, 70, 128-129. [CrossRef] 
36. Shier, W.T.; Abbas, H.K.; Baird, R.E.; Ramezani, M.; Sciumbato, G.L. (-)-Botryodiplodin, a unique ribose-analog toxin. Toxin Rev. 2007, 26, 343-386. [CrossRef]

37. Siddiqui, K.A.I.; Gupta, A.K.; Paul, A.K.; Banerjee, A.K. Purification and properties of a heat-resistant exotoxin produced by Macrophomina phaseolina (Tassi) Goid in culture. Experientia 1979, 35, 1222-1223. [CrossRef]

38. Wrather, J.A.; Anderson, T.R.; Arsyad, D.M.; Tan, Y.; Ploper, L.D.; Porta-Puglia, A.; Ram, H.H.; Yorinori, J.T. Soybean disease loss estimates for the top ten soybean-producing countries in 1998. Can J. Plant Pathol. 2001, 23, 115-121. [CrossRef]

39. Wrather, J.A.; Stienstra, W.C.; Koenning, S.R. Soybean disease loss estimates for the United States from 1996 to 1998. Can J. Plant Pathol. 2001, 23, 122-131. [CrossRef]

40. Wrather, J.A.; Koenning, S.R.; Anderson, T.R. Effect of diseases on soybean yields in the United States and Ontario (1999-2002). Plant Health Prog. 2003. [CrossRef]

41. Dunlap, J.R.; Bruton, B.D. Pigment biosynthesis by Macrophomina phaseolina: The glycine-specific requirement. Trans. Br. Mycol. Soc. 1986, 86, 111-115. [CrossRef]

42. Shier, W.T.; Abbas, H.K.; Kotowicz, J.K.; Khambhati, V. Induction of simultaneous (-)-botryodiplodin release, microschlerotia formation and enhanced hyphal branching in Macrophomina phaseolina. Mycotoxin Res. in preparation.

43. Shultz, J.L.; Ray, J.D.; Smith, J.R. Mapping two genes in the purine metabolism pathway of soybean. DNA Seq. 2008, 19, 264-269. [CrossRef]

44. Abbas, H.K.; Bellaloui, N.; Butler, A.M.; Nelson, J.L.; Abou-Karam, M.; Shier, W.T. Botryodiplodin, a toxin produced by the charcoal rot disease fungus, Macrophomena phaseolina, induces phytotoxic responses in soybean (Glycine max L.) that are of types that could be used to facilitate root infection. Toxins 2019, submitted.

(C) 2019 by the authors. Licensee MDPI, Basel, Switzerland. This article is an open access article distributed under the terms and conditions of the Creative Commons Attribution (CC BY) license (http://creativecommons.org/licenses/by/4.0/). 